\title{
Pengaruh Pelayanan Terhadap Kepuasan Konsumen Alfamart Taman Wisma Asri Dua Raya Bekasi
}

\author{
Samroh \\ Universitas Mitra Karya \\ samroh74@gmail.com
}

\begin{abstract}
This research aims to determine whether there is an effect of service on consumers of Alfamart, to find out respondents' responses to the services carried out by PT Sumber Alfaria Trijaya (Alfamart), and to find out how much influence the service has on consumer purchasing decisions at PT Sumber Alfaria Trijaya (Alfamart). in this study were consumers of PT Sumber Alfaria Trijaya (Alfamart) Bekasi, totaling 70 people. The data collection technique used questionnaires with Google com. The data analysis method used the determination test with the Cronbach's alpha formula, and the validity, reliability, and simple regression tests using SPSS program assistance. Research Results Based on the effect of service on consumer satisfaction Alfamart is $3644 \%$ ( R2). This means that the purchasing service is influenced by consumers (3644\%) in addition to being influenced by consumers. also influenced by other factors. Outside of factors, it is said that service affects consumers or product buyers at PT Sumber Alfaria Trijaya (Alfamart)
\end{abstract}

Keywords: customer service, customer satisfaction

\begin{abstract}
Abstrak
Penelitian ini bertujuan untuk mengetahui apakah terdapat pengaruh pelayanan terhadap konsumen Alfamart, untuk mengetahui tanggapan responden terhadap pelayanan yang dilaksanakan oleh PT Sumber Alfaria Trijaya ( Alfamart), dan mengetahui seberapa besar pengaruh pelayanan terhadap keputusan pembelian konsumen pada PT Sumber Alfaria Trijaya ( Alfamart) .Populasi dalam penelitian ini adalah konsumen PT Sumber Alfaria Trijaya ( Alfamart ) Bekasi, berjumlah 70 orang, Teknik pengumpulan data menggunakan penyebaran kuesioner dengan goole com.Metode analisa data menggunakan uji Deteminasi dengan rumus cronbach's alpha, dan uji validitas, reabilitas, dan regresi sederhana dengan menggunakan bantuan program SPSS.Hasil Penelitian Berdasarkan pengaruh pelayanan terhadap kepuasan konsumen Alfamart adalah 3644\% ( R2) . Hal ini berarti bahwa pelayanan pembelian selain dipengaruhi oleh konsumen (3644\%) . jug a dipengaruhi oleh faktor faktor lainnya.di luar faktor dikatakan bahwa pelayanan berpengaruh terhadap konsumen atau pembeli produk pada PT Sumber Alfaria Trijaya (Alfamart).
\end{abstract}

Kata Kunci : Pelayanan Konsumen, Kepuasan Komsumen

\section{PENDAHULUAN}

Dalam era perkembangan teknologi sekarang ini, persiangan dalam pasar pun semakin beragam.mulai dari promosi,memberikan diskon bahkan ada yang memperbaruhi produknya setiap periode tertentu. hal ini dilakukan oleh para produsen guna menarik pelanggan tidak hanya itu, bahkan ada beberapa store yang merancang ruangan, merancang bagunan,dan tata letak sedemikian rupa demi memberikan kenyamanan pelanggan.

Menurut Fandy Tjiptono (2016:4) mendefinisikan "pelayanan (service) bisa dipandang sebagai sebuah sistem yang terdiri atas dua komponen utama, yaitu service operation yang kerap kali 
tidak tampak atau tidak diketahui kebenarannyanoleh pelanggan (back office atau backstage) dan service delivery yang biasanya tampak (visible) atau diketahui pelanggan ( sering disebut from office atau frontage) PT. Sumber Alfamart Trijaya Tbk (AMRT) menyatakan pertumbuhan pendapatan hingga Sembilan bulan pertama pada tahun 2020 didorong oleh pertambahan pendapatan gerai perseoan dan entitas anak.

Direktur dan sekretaris perusahaan Sumber Alfaria Trijaya Tomin Widia menjelaskan total gerai perseoan dan entitas anak pada kuartal ketiga tahun 2020 tumbuh menjadi dari 17.129 gerai, yang terdiri dari 15.102 gerai perseoan dan 2.027 gerai entitas anak. Dalam rincianya, sebanyak 32 persen gerai perseoan dan entitas anaktersebut di jabodetabek, 37 persen tersebar diwilayah jawa non jabodetabek, dan 31 persen lainnya beredar luar pulau jawa.

Tujuan Penelitian adapun tujuan penulis melakukan penelitian ini adalah supaya dapat memecahkan masalah yang telah dirumuskan yaitu :

1. Untuk memperoleh pengetahuan atau penemuan baru.
2. Untuk membuktikan atau menguji kebenaran dari pengetahuan yang sudah ada.

3. Untuk mengembangkan pengetahuan yang sudah ada.

4. Untuk mengetahui pengaruh harga terhadap kepuasan konsumen.

5. Apakah kualitas pelayanan berpengaruh terhadap kepuasan pelanggan

Manfaat Penelitian Penelitian ini diharapkan dapat memberikan manfaat bagi pembacanya yang terurai sebagai berikut:

a. Bagi peneliti

Sebagai pengembangan wawasan antara pengetahuan teoritis yang diperoleh diperkulian dengan kondisi lapangan pekerjaan sebenarnya, serta menambah wawasan penulis mengeni pengaruh faktor kepuasan pelanggan terhadap karyawan

b. Bagi perusahaan

Sebagai tambahan informasi dan bahan masukan bagi perusahaan dalam hal meningkatkan kepuasan pelanggan.

c. Bagi Pembaca

Dengan hasil penelitian ini, diharapkan pembaca mendapatkan informasi yang berguna sebagai 
gambaran untuk penelitian lebih lanjut dengan topik yang berkaitan.

Kegunaan Teoritis,

a. sebagai bahan informasi

dan pengayaan bagi pengembangan

khasanah ilmu pengetahuan khususnya manajemen pemasaran.

b. Penelitian ini diharapkan dapat menjadi referensi untuk penelitian-penelitian selanjutnya mengenai kepuasan konsumen dalam pembelian.

Hipotesis Berdasarkan tujuan penelitian, maka rancangan hipotesis dalam penelitian adalah :

a. Hipotesis 1

Ho = Tidak dapat pengaruh antara variabel pelayanan dengan kepuasan konsumen Indomaret Taman Wisma Asri Dua Jaya Bekasi.

$\mathrm{Ha}=$ Terdapat pengaruh antara variabel penetapan pelayanan dengan kepuasan Indomaret Taman Wisma Asri Dua Jaya Bekasi

b. Hipotesis 2

Ho = Tidak terdapat hubungan antara variabel penetapan pelayanan dengan kepuasan konsumen Taman Wisma Asri Dua Jaya Bekasi

$\mathrm{Ha}=$ Terdapat hubungan antara variabel penetapan pelayanan dengan kepuasan konsumen Taman Wisma Asri Dua Jaya Bekasi

\section{METODOLOGI PENELITIAN}

Obyek Penelitian PT. Alfa minimart utama (UMA) didirikan pada tanggal 27 juli 1999, dengan pemegang saham PT. Alfa Retailindo, Tbk sebesar 51\% dan PT.Lancar Distrindo sebesar 49\% PT. Alfa Minimart pada tanggal 18 oktober 1999 berlokasi dijalan beringin raya, Karawaci Tangerang.

Sumber data dalam penelitian ini adalah data primer yang berupa wawancara, observasi secara langsung dan kuesioner yang disebarkan kepada konsumen Indomaret dan data sekunder berupa data yang diperoleh berdasarkan dokumen yang sudah ada didalamnya, seperti sejarah singkat Alfamart Taman Wisma Asri Dua Jaya Bekasi.

Tempat yang diteliti oleh peneliti di Alfamart Taman Wisma Asri Dua Jaya Bekasi.

Penelitian ini dilakukan pada bulan September 2020 sampai dengan Desember 2020. Kegiatan penyebaran kueisioner tanggal 23 hingga 25 desember yang dilakukan berupa pengumpulan data dan teori untuk menunjang penelitian dan terakhir adalah penarikan simpulan dari penelitian yang dilakukan. 
Metode deskripsi merupakan suatu metode dalam meneliti kasus sekelompok manusia, suatu objek, suatu set kondisi, suatu sistem pemikiran ataupun suatu kelas peristiwa pada masa sekarang. Tujuan dari penelitian deskriptif ini adalah untuk membuat deskripsi, gambaran, atau lukisan secara sistematis, factual dan akurat mengenai fakta, sifat serta hubungan antar fenomena Nazir (2015:63).

Metode deskriftif adalah suatu metode yang digunakan untuk menggambarkan ataumenganalisis suatau hasil penelitian tetapi tidak digunakan untuk membuat kesimpulan yanglebih luas Sugiyono (2015:21).

Menurut Sugiyono (2017:80), definisi populasi adalah "Wilayah generalisasi yang terdiri atas obyek atau subyek yang mempunyai kualitas dan karakteristik tertentu yang ditetapkan oleh peneliti untuk dipelajari dan kemudian ditarik kesimpulannya".

Populasi dalam penelitian ini adalah karyawan Alfamart wisma asri 2 bekasi karyawannya ada 5 orang .

Teknik pengumpulan data ini dilakukan dengan kuesioner. Kuesioner merupakan teknik pengumpulan data yang dilakukan dengan cara memberi seperangkat pertanyaan atau pernyataan tertulis kepada responden untuk dijawabnya. Kuesioner merupakan teknik pengumpulan data yang efisien bila peneliti tahu dengan pasti variabel yang akan diukur dan tahu apa yang bisa diharapkan dari responden. Selain itu, kuesioner juga cocok digunakan bila jumlah responden secara langsung atau dikirim melalui pos، atau internet.Sugiyono (2017: 142).

\section{Definisi operasional variabel}

Menurut Kasmadi dan Nia Sunariah (Bandung:Alpabeta, 2014:96) variabel penelitian adalah suatu atribut atau sifat atau nilai dari orang, objek, organisasi atau kegiatan yang mempunyai variasi tertentu yang ditetapkan oleh peneliti untuk dipelajari dan kemudian ditarik kesimpulannya.

Alat analisis yang di gunakan dalam penelitian ini adalah:

\section{Uji Instrumen}

Instrumen yang digunakan dalam penelitian ini menggunakan kuesioner yang dapat memberikan data yang membentuk kesiapan pada tingkat individu. Kuesioner merupakan teknik pengumpulan data yang dilakukan dengan cara memberi seperangkat pertanyaan atau pernyataan tertulis kepada responden untuk dijawabnya. 


\section{Uji Validitas}

Uji validitas adalah tingkat keandalan dan kesahihan alat ukur yang digunakan. Instrumen dikatakan valid berarti menunjukkan alat ukur yang dipergunakan untuk mendapatkan data itu valid atau dapat digunakan untuk mengukur apa yang seharusnya diukur (Marpaung, 2019).

Untuk mengetahui apakah alat ukur yang telah disusun benar-benar mengukur apa yang perlu diukur. Pengukuran ini digunakan karena penyusunan angket penelitian ini dilakukan dengan mendasarkan atas konstruksi teoritik masing-masing variabel penelitian.

\section{Uji Reliabilitas}

Menurut Ghozali, Imam (2016:47) mengatakan uji reliabilitas digunakan untuk mengukur suatu kuesioner yang merupakan indikator dari variabel atau konstruk. Kuesioner dikatakan reliabel jika jawaban seseorang terhadap pertanyaan konsisten atau stabil dari waktu ke waktu.

\section{Uji korelasi}

Korelasi merupakan salah satu teknik analisis dalam statistik yang digunakan untuk mencari hubungan antara dua variabel yang bersifat kuantitatif.

$$
r_{x y}=\frac{n \sum x i y i-\left(\sum x i\right)\left(\sum y i\right)}{\sqrt{\left\{n \sum x i^{2}-\left(\sum x i\right)^{2}\right\}-\left\{n \sum Y^{2}-\left(\sum Y i\right)^{2}\right\}}}
$$

Keterangan :

$r_{x y}=$ koefesienkorelasipearon

$x_{i}=$ variabelindependent

$y_{i}=$ variabeldependen

$n=$ banyak sampel

\section{Uji Determinasi}

Koefisien determinasi bertujuan untuk mengukur seberapa jauh kemampuan perhitungan dalam menerangkan variasi variabel terkait (independen).Nilai koefisien determinasi adalah diantara nol dan satu.

Pada pengujian hipotesis, hipotesis pertama koefisien determinasi dilihat dari besarnya nilai $\left(\mathrm{R}^{2}\right)$ untuk mengetahui seberapa jauh variabel bebas yaitu penetapan harga serta pengaruhnya terhadap minat beli. Nilai $\left(\mathrm{R}^{2}\right)$ mempunyai interval antara 0 dan 1 . Jika nilai $\mathrm{R}^{2}$ bernilai besar (mendeteksi 1) berarti variabel. bebas dapat memberikan hampir semua informasi yang dibutuhkan untuk memprediksi variabel dependen.

\section{Uji Regresi}

Regresi dipergunakan untuk mengolah hubungan antara dua variabel atau lebih, terutama untuk menelusuri pola hubungan yang modelnya belum diketahui dengan sempurna, atau untuk 
mengetahui bagaimana variabel independen berpengaruh terhadap variabel dependen dalam suatu fenomena yang komplek.Persamaan regresi digunakan untuk menguji signifikasi pengaruh variabel bebas (Pelayanan) terhadap variabel terikat (Kepuasan konsumen).

\section{Uji Hipotesis}

Uji Hipotesis merupakan jawaban sementara terhadap rumusan masalah penelitian, uji yang dipergunakan adalah Uji t (parsial) dan Uji F (simultan), berikut penjelasanya:

\section{Uji statistik $\mathbf{t}$}

Uji ini bertujuan untuk menguji pengaruh secara parsial antara variabel bebas terhadap variabel terikat dengan mengamsumsikan variabel lainnya adalah konstan. Hasil pengujian terhadap t-statistik adalah :

1. Jika sig $<\alpha, \mathrm{t}$ hitung $>\mathrm{t}$ table dan koefisien $\beta$ positif, maka hipotesis diterima.

2. Jika sig $<\alpha$ t hitung $>$ t table dari koefisien $\beta$ negatif, maka hipotesis ditolak.

Uji $\mathrm{t}$ digunakan untuk menguji apakah variabel independen secara parsial mempunyai pengaruh yang signifikan terhadap variabel dependen. Variabel independen dikatakan secara parsial berpengaruh signifikan terhadap variabel dependen apabila signifikan $($ sig) $<\alpha$ yaitu 0,05 , adapun tanda positif (+) atau negative (-) dari Beta dan t menunjukan arah variabel. Apabila negative (-) maka variabel tersebut berpengaruh negatif artinya menurunkan tingkat volume penjualan dan apabila positif (+) maka variabel independen berpengaruh positif yang berarti meningkatkan penjualan

\section{HASIL DAN PEMBAHASAN}

Uji analisis statistik deskriptif digunakan untuk mengetahui gambaran, mengenai variabel yang diteliti melalui rata-rata (mean), nilai maximum, nilai minimum, standar deviasi, dan range.

\section{Hasil Uji Validitas Variabel Pengaruh} Kepuasan konsumen(X)

Dari table 4.5 diatas menunjukan bahwa seluruh butir peryataan pada variabel pelayanan (X) adalah valid, karena nilai r-hitung setiap pernyataan lebih besar dibandingkan r-tabel jadi $\mathrm{n}=$ 70 didapat $r$ tabel $(0,278)$ dan signifikannya lebih kecil dari alpha 0,05.

Dari tabel 4.7 diatas menunjukan bahwa seluruh butir peryataan pada variabel kinerja (Y) adalah valid, karena nilai r-hitung setiap pernyataan lebih besar dibandingkan r-tabel jadi $\mathrm{n}=50$ 
didapat $r$ tabel $(0,278)$ dan signifikannya lebih kecil dari alpha 0,05 .

\section{Uji Reliabilitas}

Uji reliabilitas digunakan untuk mengukur konsistensi jawaban responden.Kriteria pengujian dilakukan dengan menggunakan pengujian Cronbach alpha. Menurut Ghozali dalam Priyatno (2013:48) “Uji reliabilitas digunakan untuk mengetahui apakah instrumen atau indikator yang digunakan dapat dipercaya sebagai alat ukur variabel, apabila nilai cronbach's alpha $(\alpha)$ suatu variabel lebih atau sama dengan 0.60 maka indikator yang digunakan oleh variabel tersebut reliabel, sedangkan nilai cronbach's alpha $(\alpha)$ suatu variabel $<0.60$ maka indikator yang digunakan oleh variabel tersebut tidak reliabel".

Tabel 1. Hasil Uji Reliabilitas

\begin{tabular}{|c|c|c|c|c|c|c|c|c|c|c|c|c|}
\hline \multicolumn{13}{|c|}{$\begin{array}{c}\text { Correlations } \\
\text { Variabel X }\end{array}$} \\
\hline & & $\mathrm{X} 1$ & X2 & $\times 3$ & X4 & $\times 5$ & $\times 6$ & $x 7$ & $x_{8}$ & X9 & $\mathrm{X} 10$ & $x 11$ \\
\hline \multirow[t]{3}{*}{ VARO0001 } & $\begin{array}{l}\text { Pearson } \\
\text { Correlation }\end{array}$ & 1 & $.544^{\prime \prime}$ & . 174 & $323^{\prime} .3$ & $390^{\circ}$ & .123 & .024 & .034 & 210 & .025 & $.334^{\prime \prime}$ \\
\hline & Sig. (2taleded) & & .000 & .149 & .006 & .001 & .309 & .843 & .783 & .082 & .838 & .005 \\
\hline & N & 70 & 70 & 70 & 70 & 70 & 70 & 70 & 70 & 70 & 70 & 70 \\
\hline \multirow[t]{3}{*}{ VARO0002 } & $\begin{array}{l}\text { Pearson } \\
\text { Correlaion }\end{array}$ & $.544^{\prime \prime}$ & 1 & $.575^{\prime \prime}$ & $.601 \% 3$ & 318" & .008 & .030 & .006 & .157 & .067 & .491" \\
\hline & Sig. (2-alaled) & .000 & & .000 & .000 & .007 & .945 & .802 & .958 & .93 & .584 & .000 \\
\hline & N & 70 & 70 & 70 & 70 & 70 & 70 & 70 & 70 & 70 & 70 & 70 \\
\hline \multirow[t]{3}{*}{ VARO0003 } & $\begin{array}{l}\text { Pearson } \\
\text { Correlaion }\end{array}$ & .174 & $.575^{\prime \prime}$ & 1 & $480^{\circ} 2$ & $279^{\circ}$ & .083 & .052 & .175 & 213 & .042 & $.483^{\prime \prime}$ \\
\hline & Siq. (2-aled) & .149 & .000 & & .000 & .019 & .493 & .670 & .147 & .076 & .729 & .000 \\
\hline & N & 70 & 70 & 70 & 70 & 70 & 70 & 70 & 70 & 70 & 70 & 70 \\
\hline \multirow[t]{3}{*}{ VAROOOOA } & $\begin{array}{l}\text { Pearson } \\
\text { Correlation }\end{array}$ & $.323^{*}$ & $.601^{\prime \prime}$ & $.480^{\circ}$ & & $378^{\prime \prime}$ & .016 & .169 & .068 & .064 & .055 & $.421^{\prime \prime}$ \\
\hline & Sig. (2-alied) & .006 & .000 & .000 & & .001 & .898 & .163 & .577 & .599 & .649 & .000 \\
\hline & N & 70 & 70 & 70 & 70 & 70 & 70 & 70 & 70 & 70 & 70 & 70 \\
\hline VAR00005 & $\begin{array}{l}\text { Pearson } \\
\text { Correlation }\end{array}$ & $.390^{\circ \prime}$ & $.318^{\prime \prime}$ & $279^{\circ}$ & $378^{*}$ & 1 & .073 & .014 & .068 & .090 & .034 & $.407 "$ \\
\hline
\end{tabular}

\begin{tabular}{|c|c|c|c|c|c|c|c|c|c|c|c|c|}
\hline & Correlation & & & & & & & & & & & \\
\hline & Sig. (2-taled) & . 001 & .007 & .019 & .001 & & 546 & .909 & .576 & 461 & .781 & .000 \\
\hline & N & 70 & 70 & 70 & 70 & 70 & 70 & 70 & 70 & 70 & 70 & 70 \\
\hline VAR00006 & Pearson & -.123 & .008 & .083 & .016 & .073 & 1 & $.279^{\circ}$ & .202 & $.327^{*}$ & $.432^{\circ}$ & $.414^{\prime \prime}$ \\
\hline & Correlation & & & & & & & & & & & \\
\hline & Sig. (2-tailed) & .309 & .945 & .493 & .898 & 546 & & .019 & .093 & .006 & .000 & .000 \\
\hline & $\mathrm{N}$ & 70 & 70 & 70 & 70 & 70 & 70 & 70 & 70 & 70 & 70 & 70 \\
\hline VAR00007 & Pearson & .024 & .030 & .052 & -169 & .014 & $279^{\circ}$ & 1 & $.446^{\prime \prime}$ & 225 & $.342^{\prime \prime}$ & $.385^{\prime \prime}$ \\
\hline & Correlation & & & & & & & & & & & \\
\hline & Siq. (2-taled) & .843 & 802 & .670 & .163 & 909 & .019 & & .000 & .061 & .004 & .001 \\
\hline & N & 70 & 70 & 70 & 70 & 70 & 70 & 70 & 70 & 70 & 70 & 70 \\
\hline VAR00008 & Pearson & .034 & .006 & .175 & .068 & .068 & 202 & $.446^{\prime \prime}$ & 1 & $.401^{\prime \prime}$ & $.629^{\prime \prime}$ & .426 \\
\hline & Correlation & & & & & & & & & & & \\
\hline & Sig. (2-tailed) & .783 & 958 & .147 & .577 & .576 & .093 & .000 & & .001 & .000 & .000 \\
\hline & N & 70 & 70 & 70 & 70 & 70 & 70 & 70 & 70 & 70 & 70 & 70 \\
\hline VAR00009 & Pearson & .210 & .157 & .213 & .064 & .090 & .327 & .225 & $.401^{\prime}$ & 1 & $.436^{\circ}$ & $.410^{\prime \prime}$ \\
\hline & Correlation & & & & & & & & & & & \\
\hline
\end{tabular}

\begin{tabular}{|c|c|c|c|c|c|c|c|c|c|c|c|c|}
\hline \multirow{2}{*}{. } & Sig. (2-tailed) & .082 & .193 & .076 & 599 & .461 & .006 & .061 & .001 & & .000 & .000 \\
\hline & N & 70 & 70 & 70 & 70 & 70 & 70 & 70 & 70 & 70 & 70 & 70 \\
\hline \multirow[t]{4}{*}{ VAR00010 } & Pearson & .025 & .067 & .042 & .055 & .034 .4 & 432" & $.342^{\prime \prime}$ & $.629^{\prime \prime}$ & .436 & 1 & $.465^{\circ}$ \\
\hline & Correlation & & & & & & & & & & & \\
\hline & Sig. (2-tailed) & .838 & .584 & .729 & .649 & .781 & .000 & .004 & .000 & .000 & & .000 \\
\hline & N & 70 & 70 & 70 & 70 & 70 & 70 & 70 & 70 & 70 & 70 & 70 \\
\hline \multirow[t]{4}{*}{ VARO0011 } & Pearson & $.334^{\prime \prime}$ & $.491^{\prime \prime}$ & $.483^{\prime \prime}$ & $.421^{\prime \prime}$ & $407^{\prime \prime} .4$ & $414^{\prime \prime}$ & $.385^{\prime \prime}$ & $.426^{\prime \prime}$ & $410^{\prime \prime}$ & $.465^{\prime \prime}$ & 1 \\
\hline & Correlation & & & & & & & & & & & \\
\hline & Sig. (2-tailed) & .005 & .000 & .000 & .000 & .000 & .000 & .001 & .000 & .000 & .000 & \\
\hline & $\mathrm{N}$ & 70 & 70 & 70 & 70 & 70 & 70 & 70 & 70 & 70 & 70 & 70 \\
\hline
\end{tabular}

\section{Correlations} Variabel Y

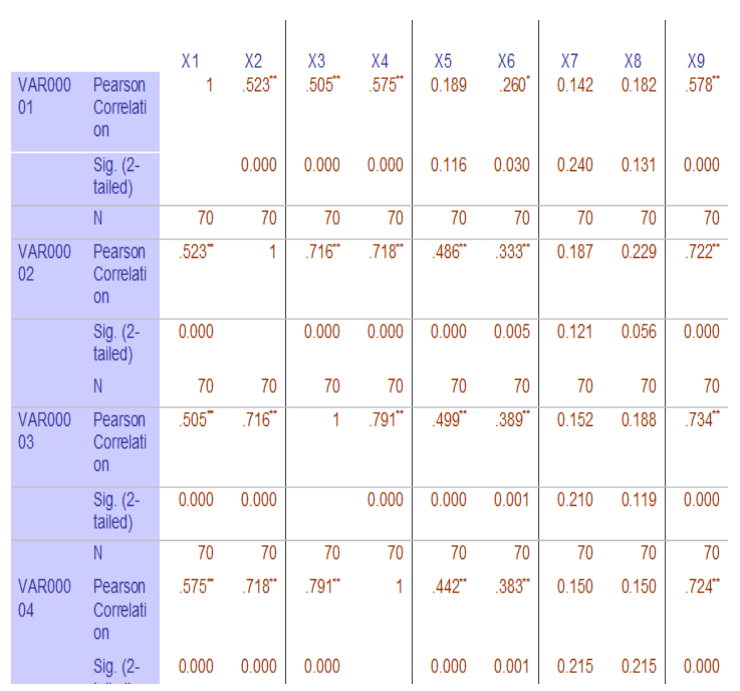




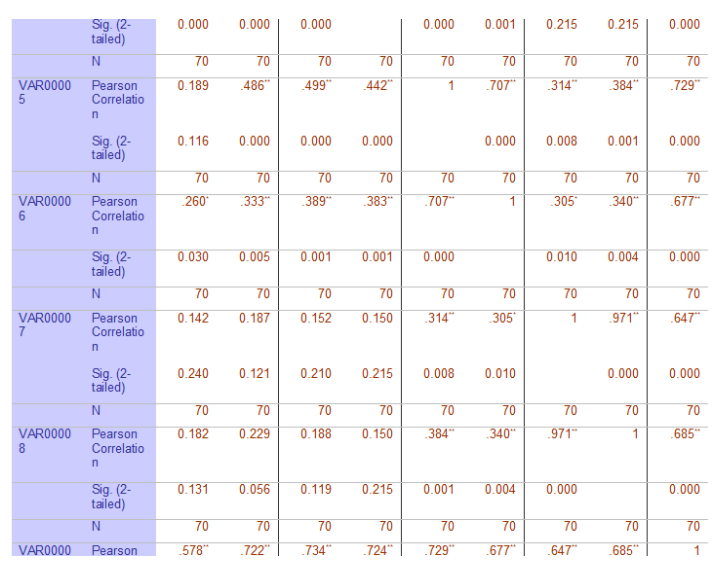

Sumber: Data diolah SPSS 19.0 (2020)

Berdasarkan hasil uji reliabilitas pada tabel 2 di atas didapat hasil dari variabel pengaruh pelayanan $(\mathrm{X})$ dimana dari tabel tersebut dapat diketahui nilai reliabilitas (Cronbach's Alpha) sebesar $0,674>0,10$ sehingga dapat disimpulkan bahwa alat ukur dalam penelitian ini adalah reliabel.

Tabel 3.Hasil Uji Reliabilitas Variabel Kepuasan Konsumen Alfamart (Y)

\section{Reliability Statistics}

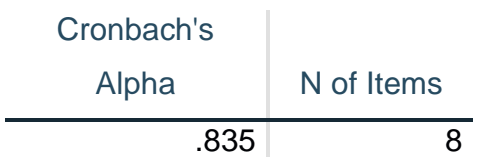

Sumber: Data diolah SPSS 19.0(2020)

Berdasarkan hasil uji reliabilitas pada tabel 3 di atas didapat hasil dari variabel kepuasan konsumen Alfamart (Y) dimana dari tabel tersebut dapat diketahui nilai reliabilitas (Cronbach's Alpha) sebesar $0,835>0,8$ sehingga dapat disimpulkan bahwa alat ukur dalam penelitian ini adalah reliabel.

Hasil Dan Pembahasaan Uji Kolerasi (R)

Untuk mengukur seberapa kuat hubungan variabel bebas yaitu di pengaruh pelayan $(\mathrm{X})$ dan (Y) dapat dilakukan dengan menghitung besarnya koefisen korelasi (R) dari setiap variabel secara partial, hasil dari SPSS versi 19.0 sebagai berikut:

\section{Tabel 4}

Hasil Uji Korelasi (R)

\begin{tabular}{|l|r|c|}
\hline Model & $\mathrm{R}$ & $\begin{array}{c}\text { Std. Error of the } \\
\text { Estimate }\end{array}$ \\
\hline 1 & $500^{\mathrm{a}}$ & 1.095 \\
\hline
\end{tabular}

a. Predictors: (Constant), pelayanan, kepuasan konsumen.

Sumber: Data diolah SPSS 19.0 (2020)

Berdasarkan tabel 4 di atas, hasil uji coba model summarydiketahui nilai $\mathrm{R}$ $=0,500$ maka nilai tersebut menggambarkan tigkat hubungan yang kuat antara variabel dan (kepuasan konsumen Alfamrt) terhadap kinerja karyawan.

\section{Hasil Dan Pembahasan Uji}

Determinasi $\left(\mathbf{R}^{2}\right)$ 
Tabel 5. Hasil Uji Determinasi $\left(\mathbf{R}^{2}\right)$

\begin{tabular}{|l|r|r|r|}
\hline $\begin{array}{l}\text { Mode } \\
1\end{array}$ & $\begin{array}{c}\mathrm{R} \\
\text { Square }\end{array}$ & $\begin{array}{c}\text { Adjusted R } \\
\text { Square }\end{array}$ & $\begin{array}{l}\text { Std. Error of } \\
\text { the Estimate }\end{array}$ \\
\hline 1 & 051, & 3.644 & 060 \\
\hline
\end{tabular}

Dependent Variabel: kepuasan konsumen

Sumber: Data diolah SPSS 19.0 (2020)

Uji determinasi $\left(\mathrm{R}^{2}\right)$ mengukur seberapa jauh kemampuan dalam menerangkan pengaruh variasi variabel independen. Koefisien determinasi dilihat dari angka pada Adjusted $R$ Square sebesar 0,051 hal ini menunjukkan bahwa persentase sumbangan pengaruh variabel bebas yaitu variabel pelayanan dan (kepuasan konsumen) dapat memberikan kontribusi pengaruh sebesar $3.644 \%$ terhadap variabel terikat yaitu Kepuasan dan selebihnya $0,60 \%$ dipengaruhi oleh variabel lain yang tidak dimasukkan dalam model penelitian ini.

\section{Hasil Dan Pembahasan Uji Regresi}

Analisis ini digunakan untuk memprediksi nilai dari variabel terikat apabila nilai variabel bebas mengalami kenaikan atau penurunan, dan untuk mengetahui arah hubungan antara variabel bebas dengan variabel terikat apakah masing-masing variabel bebas dengan variabel terikat berhubungan positif atau negatif.
Tabel 6

\section{Hasil Uji Koefisien Regresi}

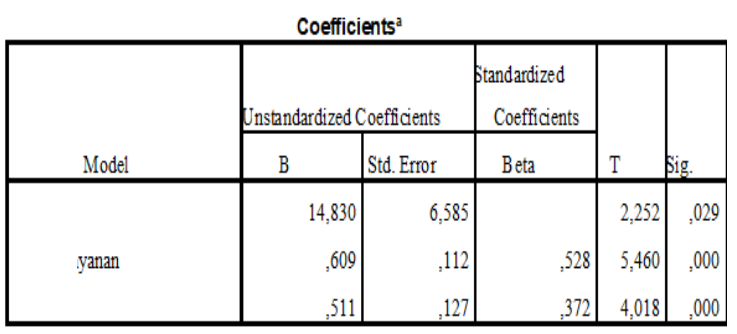

ependent $V$ ariable: Pelayanan

Sumber: Data diolah SPSS 19.0 (2020)

Berdasarkan tabel 4.13 di atas hasil pengujian analisi regresi linier berganda apabila hasil tersebut dimasukkan dalam bentuk persamaan regresi berganda adalah sebagai berikut:

$$
\begin{aligned}
& Y=\alpha+\beta_{1} X_{1}+\beta_{2} X_{2}+e \\
& Y=14,830+0,609 X_{1}+0,511 X_{3}+e
\end{aligned}
$$

Keterangan:

$\mathrm{Y}=$ Variabel terikat (kepuasan konsumen)

$\mathrm{X}=$ Variabel bebas (pengaruh kepuasan konsumen)

Jika dilihat dari persamaan regresi linier berganda di atas dapat dijelaskan sebagai berikut:

1. Koefisien regresi variabel pelayanan sebesar 0,609 artinya jika variabel disiplin mengalami kenaikan satu satuan, maka variabel kinerja akan mengalami peningkatan sebesar 0,609 satuan dengan asumsi variabel lainnya bernilai tetap. 
2. Koefisien regresi variabel (Kepuasan konsumen Alfamart) sebesar 0,511 artinya jika variabel (Kepuasan konsumen Alfamart) mengalami kenaikan satu satuan, maka variabel kinerja akan mengalami peningkatan sebesar 0,511 satuan dengan asumsi variabel lainnya bernilai tetap.

\section{Uji t (Parsial)}

Dasar dari pengambilan keputusan untuk pengujian secara parsial ini adalah dengan membandingkan signifikan dengan $\alpha$ sebesar 0,05 . Jika signifikan <alpha 0,05 maka Ho ditolak dan sebaliknya jika signifikan >alpha 0,05 maka Ho diterima.

Untuk meyakinkan apakah angkaangka koefisien tersebut dapat digunakan sebagai model untuk menentukan prestasi kerja karyawan, maka angka-angka tersebut akan diuji dengan menggunakan uji t. Uji t dilakukan dengan tingkat signifikan $(\alpha)$ $=5 \%$, derajat kebebasan (degree of freedom $(\mathrm{df})=50-3-1=46)$, maka menghasilkan $\quad \mathrm{T}_{\text {tabelsebesar }} 2,013$. Ketentuan penerimaan hipotesis yaitu:

- Jikat $_{\text {hitung }}>t_{\text {tabel }}$ dan Signifikan < 0,05 maka Ho ditolak dan $\mathrm{Ha}$ diterima
- Jika $t_{\text {hitung }}<\mathrm{t}_{\text {tabel }}$ dan Signifikan $>$ 0,05 maka Ho diterima dan $\mathrm{Ha}$ ditolak

\section{Gambar7. Kurva Uji t (Parsial)}

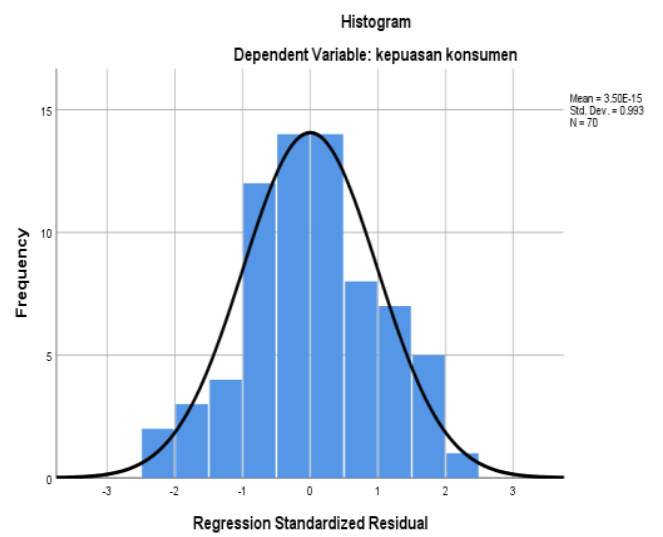

Sumber:Data diolah SPSS

Tabel 8. Hasil Uji t (Parsial)

\begin{tabular}{|c|c|c|c|c|c|}
\hline \multirow[b]{2}{*}{ del } & \multicolumn{2}{|c|}{$\begin{array}{r}\text { Unstandardized } \\
\text { Coefficients }\end{array}$} & \multirow{2}{*}{\begin{tabular}{|c|}
$\begin{array}{c}\text { tandardized } \\
\text { Coefficients }\end{array}$ \\
Beta \\
\end{tabular}} & \multirow[b]{2}{*}{$\mathrm{T}$} & \multirow[b]{2}{*}{$\mathrm{Sig}}$. \\
\hline & B & itch. Error & & & \\
\hline Instant) & 14,830 & 6,585 & & 2,252 & 029 \\
\hline puasan & 609 & ,112 &, 528 & 5,460 & ,000 \\
\hline & ,511 & ,127 &, 372 & 4,018 & ,000 \\
\hline
\end{tabular}

ependent $V$ aniable: kepuasan konsumen

\section{Sumber:Data diolah SPSS}

Berdasarkan tabel di atas, dapat disimpulkan bahwa variabel disiplin kerja dan (Kepuasan konsumen Alfamart) signifikan secara parsial terhadap kinerja kerja karyawan karena masing-masing variabel memiliki nilai $t_{\text {hitung }}$ lebih besar dari pada $t_{\text {tabel }}$ dan nilai signifikan dibawah tingkat kesalahan (alpha) sebesar 0,05. 


\section{KESIMPULAN}

Berdasarkan table dan gambar, dapat diketahui nilai thitung lebih besar dari pada $t_{\text {tabel }}$ atau 5,460 > 2,013 dan nilai signifikansi jauh dibawah tingkat kesalahan (alpha) sebesar 0,05 atau $0,000<0,050$. Sehingga dapat disimpulkan bahwa :

Terdapat pengaruh disiplin terhadap pengaruh pelayanan pada Alfamart

Terdapat hubungan disiplin terhadap pengaruh pelayanan pada Alfamart

Berdasarkan table dan gambar, dapat diketahui nilai $t_{\text {hitung }}$ lebih besar dari pada $t_{\text {tabel }}$ atau 4,018 > 2,013 dan nilai signifikansi jauh dibawah tingkat kesalahan (alpha) sebesar 0,05 atau $0,000<0,050$. Sehingga dapat disimpulkan bahwa:

Terdapat Pengaruh (kepuasan konsumen Alfamart) terhadap kinerja karyawan pada Alfamart.

\section{REFERENCES}

Fady Tripno (2016:4) Mendefinisikan Pelayanan

Ghazali imam (2016:52-53)Mengukur Sah Tidaknya Suatu Koesioner.
(2016:47) Uji Reabilitas.

(2011:48) Menguji Reabilitas.

$$
\text { (2017:97) Nilai Koevisien }
$$

Determinasi.

$\begin{array}{cr}\text { Haryanto,R.A (2013) } & \text { Strategi } \\ \text { Promosi,Kualitas } & \text { Produk, } \\ \text { Kualitas Layanan } & \text { Terhadap } \\ \text { Kepuasan Pelanggan. } & \end{array}$

Haryanto, David (2013), Analisis Pengaruh Dimensi Kualitas Pelayanan Terhadap Kepuasan Pelanggan.

Kotler dan Keller (2016:153) Tujuan Bisnis Kepuasan Konsumen.

$\begin{array}{rlr}\text {.........Dalam } & \text { Fandy } & \text { Triptono } \\ (2016: 284) & \text { Kriteria } & \text { Penentuan }\end{array}$ Kualitas Jasa.

Khoirista,Afrinda (2015) Pemgaruh Kualitas Pelayanan Terhadap Kepuasan Pelanggan.

Lembang R.D\& Sugiono,S (2010), Analisis Pemgaruh Kualitas Produk, Terhadap Kepuasan Pembeli.

Marpaung, N. N. (2019). ANALISIS

TINGKAT KEPUASAN PASIEN

TERHADAP PELAYANAN

KLINIK DAN RUMAH 


\section{BERSALIN BIDAN UMI}

RAHMA. PARAMETER, 4(1).

https://doi.org/10.37751/parameter. v4i1.27

Nugroho Dalam Purnomo Edwin Setyo(2017)Kepusan Konsumen Merupakan Salah Satu Elemen

Penting Dalam Peningkatan Kinerja Pemasaran.

Parasuratman, Zaithml dan Berry (Triptono 2016:136-137)

Mengindentifikasi Sepuluh

Dimensi Pokok Kualitas Jasa.

Rizky Natasya (2012) Infortanse Performance Analisis Dimensi Kualitas Pelayanan Jasa Alfamart Terhadap Kepuasn Konsumen.

Rizan,M,\& Andika,F (2017),Pengaruh Kualitas Produk dan Kualitas Pelayanan Terhadap Kepuasan Pelanggan.

Sugiyono (2016:96) Hipotesis. ...(2017:80) Populasi Sampel. ..(2017:81) Sampel. (2015:64) Teknik Rendem Sampling.
Sanidini,B,\&Arifin,F (2017)
aruh Kualitas Produk dan Kualitas

Sanidini,B,\&Arifin,F (2017)
Pengaruh Kualitas Produk dan Kualitas Terhadap Kepuasan Konsumen.

\begin{tabular}{lcc}
\multicolumn{1}{c}{ Sidik } & Rustam & Aji(2017) \\
Pengaruh $\quad$ Kualitas & Pelayanan, \\
Harga,Terhadap & Loyaliatas & Konsumen \\
dan Kepuasan. & &
\end{tabular}
Variabel. ..(2016:93) Indikator

Variabel.

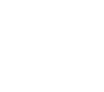

